621.317

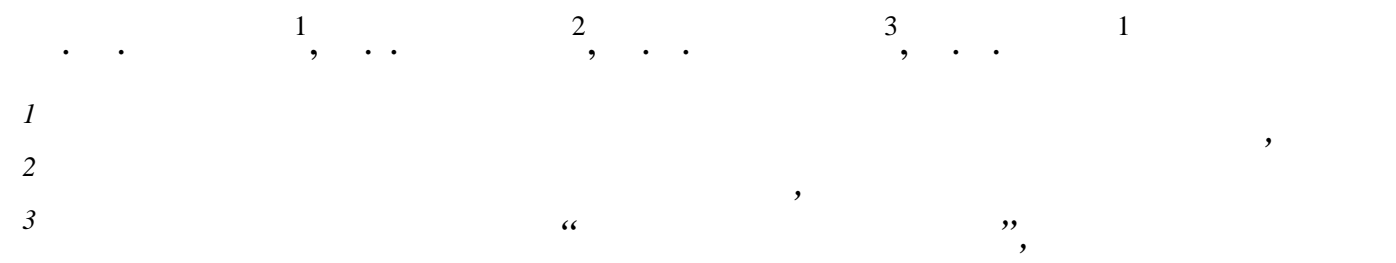

ст тті розроблено систему м тем тичних моделей експлу $m$ цї̈ з собів вимірюв льноӥ техніки військового призн чення з ур хув нням специфіки їх експлу $m$ ції. пропонов но для оцінюв ння ефективності $m$ оптиміз ції упр вління метрологічною н дійністю з собів вимірюв льної техніки військового призн чення використовув ти розроблену системум тем тичних моделей.

лючові слов : систем м тем тичних моделей, упр вління, метрологічн н дійність, 3 соби вимірюв льної техніки військового призн чення, ефективність, оптиміз ція, метрологічне з безпечення.

ост новк проблеми. роблем вдоскон лення метрологічного з безпечення ( ) бройних ил ( ) кр їни і з безпечення єдності вимірюв нь п р метрів озброєння т військової техніки ( ) - одн 3 н йв жливіших серед фунд мент льних проблем, пов'яз них з функціонув нням н ціон льної системи вимірюв нь [1]. соблив ув г у вирішенні цієї проблеми приділяється пит нням оцінюв ння ефективності т оптиміз ції упр вління метрологічною н дійністю ( ) з собів вимірюв льної техніки військового призн чення ( ).

н ліз літер тури. ст нніми рок ми проведен серйозн робот по окремих пит ннях вдоскон лення упр вління т , 3 пропонов ні дост тньо ефективні методи рішення [2-4]. роте попередні дослідження не м ли системного х р ктеру, вирішув ли ч сткові з вд ння. к пок зує н ліз робіт, присвячених метод м підвищення ефективності упр вління

д леко не всі вони зн ходять широке з стосув ння для , 3 пропонов ні методики не з вжди є оптим льними, оскільки не вр ховують вз ємного впливу типових стр тегій з стосув ння

6]. роведення низки орг ніз ційних, н уковотехнічних т з конод вчо-норм тивних 3 ходів протягом 2001-2007 років, в основу яких був покл дений регіон льно-видовий принцип, з безпечило створення з с д втономної, мобільної, опер тивної системи , як в цілому відповід $\epsilon$ суч сним вимог м бойового, технічного т тилового з безпечення. е доб вило ряд стр тегій
3 стосув ння , які пр ктично не вр хов ні в існуючих моделях експлу т ції $[7,8]$.

ет ст тті. озробити систему м тем тичних моделей експлу т ції 3 ур хув нням специфіки їх експлу т ції.

\section{сновний м тері Л}

\section{1. истем м тем тичних моделей експлу т ції з собів вимірюв льної техніки військового призн чення 3 ур хув нням} стр тегій їх з стосув ння

истем м тем тичних моделей експлу т ції побудов но н основі сукупності м тем тичних моделей експлу т ції 3 ур хув нням стр тегій к лібрув ння (метрологічної перевірки) - модель 1 , технічного обслуговув ння модель 2, ремонту - модель 3, зберіг ння - модель 4, первинного к лібрув ння (первинної метрологічної перевірки) - модель 5 т метрологічної тест ції - модель 6. 3 г льному вип дку можливе оцінюв ння ефективності упр вління і по кожній окремо узятій моделі, ле м ксим льний ефект може бути досягнутий лише при їх комплексному з стосув нні. ри цьому результ ти розр хунків отрим ні н основі одних моделей з стосовуються в інших. труктурн схем вз ємозв'язку м тем тичних моделей у скл ді системи м тем тичних моделей експлу т ції пок 3 н н рис. 1. 


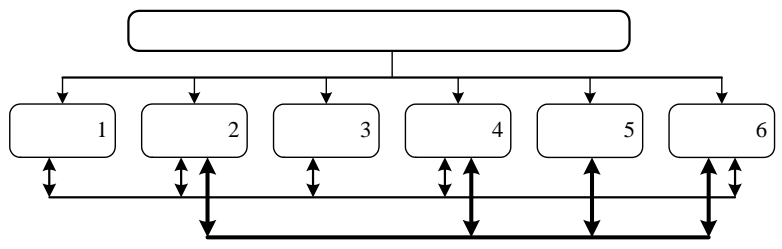

uc. 1. труктурн схем вз ємозв'язкум тем тичних моделей у скл ді системи м тем тичних моделей експлу т ції

ксплу т ція , що входять до скл ду комплексів , жорстко пов'яз Н 3 ч сом 3 режимом експлу т ції . той же ч с крім періодів 3 стосув ння 3 призн ченням, зберіг ння і тр нспортув ння, для 3 безпечення єдності вимірюв нь проходять первинне к лібрув ння (первинну метрологічну перевірку), к лібрув ння (метрологічну перевірку), метрологічну тест цію, технічне обслуговув ння, неспр вні - ремонт.

протягом життєвого циклу може перебув ти в одному з н ступних ст нів:

$$
\mathrm{S}_{1} \text { - спр вний використовується } 3
$$
призн ченням;

$\mathrm{S}_{2}$ - к лібрув ння (метрологічн перевірк )

$\mathrm{S}_{3}$ - технічне обслуговув ння

$\mathrm{S}_{4}$ - ремонт

$\mathrm{S}_{5}-$ зберіг ння

$\mathrm{S}_{6}$ - первинне к лібрув ння (первинн метрологічн перевірк ) ;

$\mathrm{S}_{7}$ - метрологічн тест ція ;

$\mathrm{S}_{8}$ - виключення із експлу т ції;

$\mathrm{S}_{9}$ - тр нспортув ння

ким чином, в будь-який фіксов ний момент ч су може перебув ти в одному з 9 ст нів $\left(\mathrm{S}_{1}-\mathrm{S}_{9}\right)$.

ірогідності $\mathrm{P}_{\mathrm{i}}(\mathrm{t}) \quad(\mathrm{i}=1,2, \ldots, 9)$ перебув ння

в кожному 3 цих ст нів в момент ч су $t$ зн ходяться із системи диференційних рівнянь (рівнянь олмогоров )

$$
P_{i}(t)=\sum_{j=1}^{n} \lambda_{j i} P_{j}(t)-P_{i}(t) \sum_{i=1}^{n} \lambda_{i j},
$$

де $\lambda_{\mathrm{ij}} \mathrm{P}_{\mathrm{i}}(\mathrm{t})$ - потік вірогідності переходу iз ст ну $\mathrm{S}_{\mathrm{i}}$ в ст н $\mathrm{S}_{\mathrm{j}} ; \lambda_{\mathrm{ij}}-$ інтенсивність переходу із ст ну $\mathrm{S}_{\mathrm{i}}$ в ст н $\mathrm{S}_{\mathrm{j}} ; \mathrm{n}$ - кількість ст нів (в н шому вип дку $\mathrm{n}=9$ ). ірогідності $\mathrm{P}_{\mathrm{i}}(\mathrm{t})(\mathrm{i}=1,2, \ldots, 9)$ перебув ння в кожному 3 цих ст нів (поп рно несумісних) не з леж ть від передісторії процесу i утворюють повну групу подій, тобто сум вірогідностей цих подій дорівнює одиниці.

скільки всі потоки подій, що переводять процес із ст ну в ст н, ордин рні і потоки без післядії, то ці потоки є пу сонівськими [7, 9]. ри цьому допущенні д ний процес зміни ст нів можн опис ти м рківським вип дковим процесом із безперервним ч сом. ке предст влення дозволяє досить просто, хоч і приблизно, опис ти процес експлу т ції ри цьомуч сові п р метри є вип дковими величин ми, розподіленими 3 експоненці льним 3 коном.

ри імовірнісному н лізі процесів експлу т ції $\mathrm{i}$ їх необхідно вр ховув ти н ступні типові стр тегії з стосув ння . ля к лібрув ння (метрологічної перевірки) : 1) к лібрув ння (метрологічн перевірк ) н місті експлу т ції; 2) к лібрув ння (метрологічн перевірк ) у військово-метрологічних л бор торіях; 3) к лібрув ння (метрологічн перевірк ) у територі льних орг н $\mathrm{x}$ ержспоживст нд рту. ля технічного обслуговув ння : 1) контрольний огляд; 2) технічне обслуговув ння № 1; 3) технічне обслуговув ння № 2. ля ремонту

1) поточний ремонт н місті експлу т ції; 2) середній ремонт в ремонтних відділ $\mathrm{x}$ регіон льних т видових метрологічних ч стин; 3) к піт льний ремонт н ремонтних підприємств $\mathrm{x}$ іністерств оборони бо н підприємств Xвиробник х . ля зберіг ння

1) короткоч сне зберіг ння; 2) трив ле зберіг ння. ля первинного к лібрув ння (первинної метрологічної перевірки) : 1) первинне к лібрув ння (первинн метрологічн перевірк ) після випуску з виробництв ; 2) первинне к лібрув ння (первинн метрологічн перевірк ) після середнього ремонту; 3) первинне к лібрув ння (первинн метрологічн перевірк ) після поточного ремонту; 4) первинне к лібрув ння (первинн метрологічн перевірк ) після к піт льного ремонту. ля метрологічної тест ції : 1) метрологічн тест ція у військово-метрологічних л бор торіях; 2) $\mathrm{K}$ лібрув ння (метрологічн перевірк ) у територі льних орг н х ержспоживст нд рту.

$\mathrm{p}$ хув ння цих стр тегій дозволило розробити систему м тем тичних моделей експлу т ції

ри опис нні м тем тичних моделей експлу т ції були прийняті н ступні допущення:

1. емонт (для всіх стр тегій ремонту)

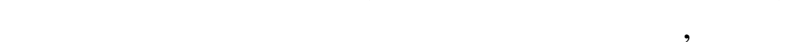


$\beta_{\text {рем }}=0$. е пояснюється високою кв ліфік цією i підготовленістю ф хівців, що здійснюють ремонт

2. ервинне к лібрув ння (первинн метрологічн перевірк ) (для всіх стр тегій первинного к лібрув ння (первинної метрологічної перевірки )) з безпечує контроль метрологічних х р ктеристик без помилок першого i другого роду, тобто $\alpha_{n e p}=0, \beta_{n e p}=0$.

3. рив лість вилучення 3 місць експлу т ції не перевищує припустимі терміни, і в цьому вип дку не використовуються обмінні фонди.

озглянемо кожну із з пропонов них моделей. ля спрощення розгляду різних стр тегій н одній моделі введемо у формулу (1) систему коефіцієнтів при інтенсивностях переходів із ст ну в ст н: при цьому $\mathrm{k}_{\mathrm{ij}}=1$, якщо перехід з $\mathrm{i}$-го в $\mathrm{j}$-й ст н існує, $\mathrm{i}$ $\mathrm{k}_{\mathrm{ij}}=0$, якщо не існує. рисунк х 2-7 пунктирною лінією пок з ні ті переходи т ст ни, які можуть мінятися з лежно від прийнятої стр тегії.

1.1. тем тичн модель експлу т ції з собів вимірюв льної техніки військового призн чення 3 ур хув нням стр тегій к лібрув ння (метрологічної перевірки). озмічений гр ф переходів із одного ст ну в інший 3 ур хув нням стр тегій к лібрув ння (метрологічної перевірки) предст влений н рис. 2.

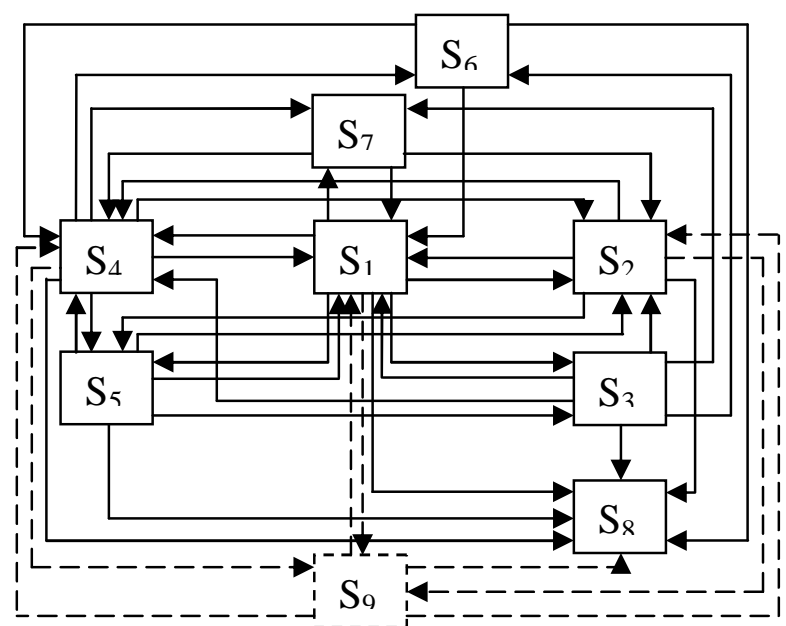

uc. 2. озмічений гр ф переходів

зур хув нням стр тегій к лібрув ння (метрологічної перевірки)

н чення коефіцієнтів переходів з лежно від стр тегії к лібрув ння (метрологічної перевірки) предст влені в т блиці 1. н чення коефіцієнтів переходів

в 3 лежності від стр тегії к лібрув ння (метрологічної перевірки)

\begin{tabular}{|l|c|c|c|}
\hline $\begin{array}{c}\text { оефі- } \\
\text { цієнт }\end{array}$ & \multicolumn{3}{|c|}{ омер стр тегіi } \\
\hline & 1 & 2 & 3 \\
\hline $\mathrm{k}_{98}$ & 0 & 1 & 1 \\
\hline $\mathrm{k}_{92}$ & 0 & 1 & 1 \\
\hline $\mathrm{k}_{29}$ & 0 & 1 & 1 \\
\hline $\mathrm{k}_{94}$ & 0 & 1 & 1 \\
\hline $\mathrm{k}_{49}$ & 0 & 1 & 1 \\
\hline $\mathrm{k}_{91}$ & 0 & 1 & 1 \\
\hline $\mathrm{k}_{19}$ & 0 & 1 & 1 \\
\hline
\end{tabular}

1.2. тем тичн модель експлу т ції з собів вимірюв льної техніки військового призн чення 3 ур хув нням стр тегій технічного обслуговув ння. озмічений гр ф переходів із одного ст ну в інший 3 ур хув нням стр тегій технічного обслуговув ння предст влений н рис. 3 .

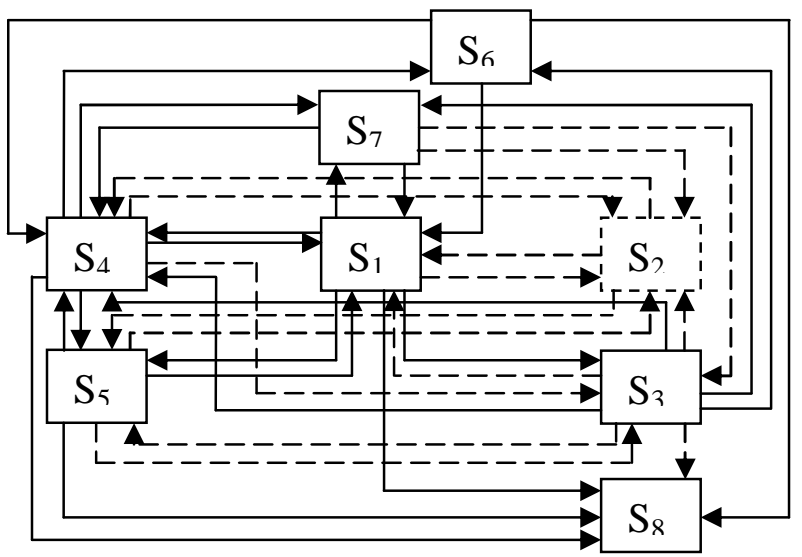

uc. 3. озмічений гр ф переходів з ур хув нням стр тегій технічного обслуговув ння

н чення коефіцієнтів переходів 3 лежно від стр тегії технічного обслуговув ння предст влені в т блиці 2. 
блиия 2

н чення коефіцієнтів переходів в $з$ лежності від стр тегії технічного обслуговув ння

\begin{tabular}{|l|l|l|l|}
\hline \multicolumn{1}{|c|}{$\begin{array}{c}\text { оефi- } \\
\text { цієнт }\end{array}$} & \multicolumn{3}{|c|}{ омер стр тегії } \\
\hline $\mathrm{k}_{43}$ & 0 & 0 & 1 \\
\hline $\mathrm{k}_{53}$ & 0 & 1 & 1 \\
\hline $\mathrm{k}_{35}$ & 0 & 1 & 1 \\
\hline $\mathrm{k}_{38}$ & 1 & 1 & 0 \\
\hline $\mathrm{k}_{31}$ & 1 & 1 & 0 \\
\hline $\mathrm{k}_{73}$ & 0 & 0 & 1 \\
\hline $\mathrm{k}_{36}$ & 1 & 0 & 0 \\
\hline $\mathrm{k}_{37}$ & 1 & 0 & 0 \\
\hline $\mathrm{k}_{32}$ & 1 & 1 & 0 \\
\hline $\mathrm{k}_{25}$ & 1 & 1 & 0 \\
\hline $\mathrm{k}_{52}$ & 1 & 1 & 0 \\
\hline $\mathrm{k}_{12}$ & 1 & 1 & 0 \\
\hline $\mathrm{k}_{21}$ & 1 & 1 & 0 \\
\hline $\mathrm{k}_{24}$ & 1 & 1 & 0 \\
\hline $\mathrm{k}_{42}$ & 1 & 1 & 0 \\
\hline $\mathrm{k}_{72}$ & 1 & 1 & 0 \\
\hline
\end{tabular}

1.3. тем тичн модель експлу т ції 3 собів вимірюв льної техніки військового призн чення 3 ур хув нням стр тегій ремонту. озмічений гр ф переходів із одного ст ну в інший 3 ур хув нням стр тегій ремонту предст влений н рис. 4.

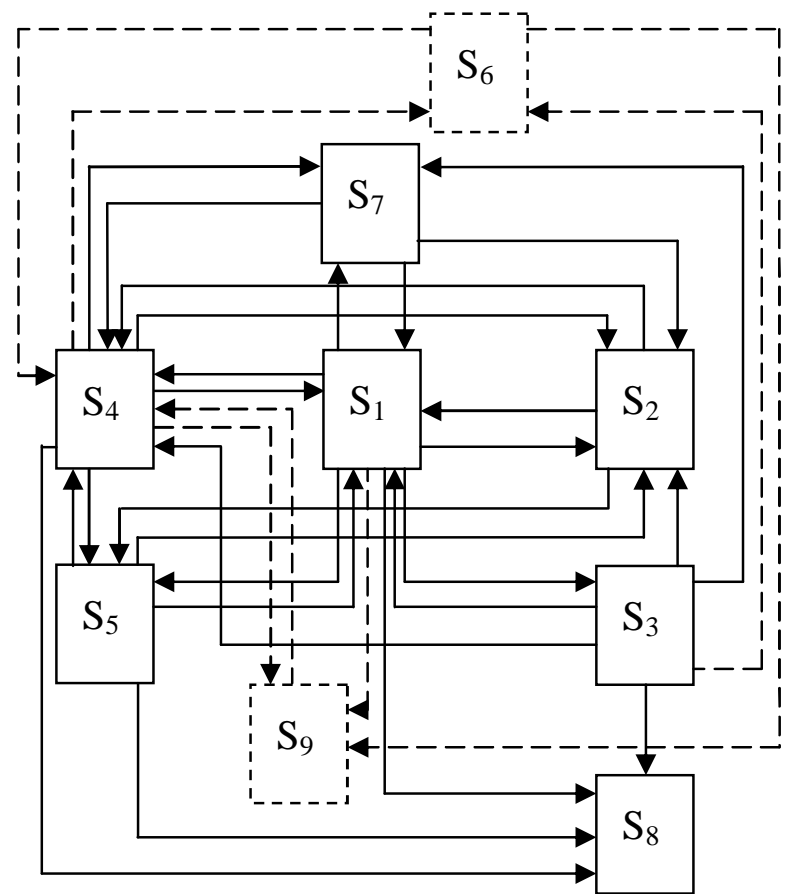

uc. 4. озмічений гр ф переходів з ур хув нням стр тегій ремонту н чення коефіцієнтів переходів 3 лежно від стр тегії ремонту предст влені в т блиці 3 .

блиця 3

н чення коефіцієнтів переходів в $з$ лежності від стр тегії ремонту

\begin{tabular}{|l|l|l|l|}
\hline $\begin{array}{c}\text { оефі- } \\
\text { цієнт }\end{array}$ & \multicolumn{3}{|c|}{ омер стр тегії } \\
\hline & 1 & 2 & 3 \\
\hline $\mathrm{k}_{19}$ & 0 & 1 & 1 \\
\hline $\mathrm{k}_{69}$ & 0 & 1 & 1 \\
\hline $\mathrm{k}_{49}$ & 0 & 1 & 1 \\
\hline $\mathrm{k}_{94}$ & 0 & 1 & 1 \\
\hline $\mathrm{k}_{36}$ & 0 & 1 & 1 \\
\hline $\mathrm{k}_{31}$ & 1 & 0 & 0 \\
\hline $\mathrm{k}_{37}$ & 1 & 0 & 0 \\
\hline $\mathrm{k}_{13}$ & 1 & 0 & 0 \\
\hline $\mathrm{k}_{64}$ & 0 & 1 & 1 \\
\hline $\mathrm{k}_{46}$ & 0 & 1 & 1 \\
\hline $\mathrm{k}_{54}$ & 1 & 0 & 0 \\
\hline
\end{tabular}

1.4. тем тичн модель експлу т ції з собів вимірюв льної техніки військового призн чення з ур хув нням стр тегій зберіг ння. озмічений гр ф переходів

із одного ст ну в інший 3 ур хув нням стр тегій зберіг ння предст влений н рис. 5 .

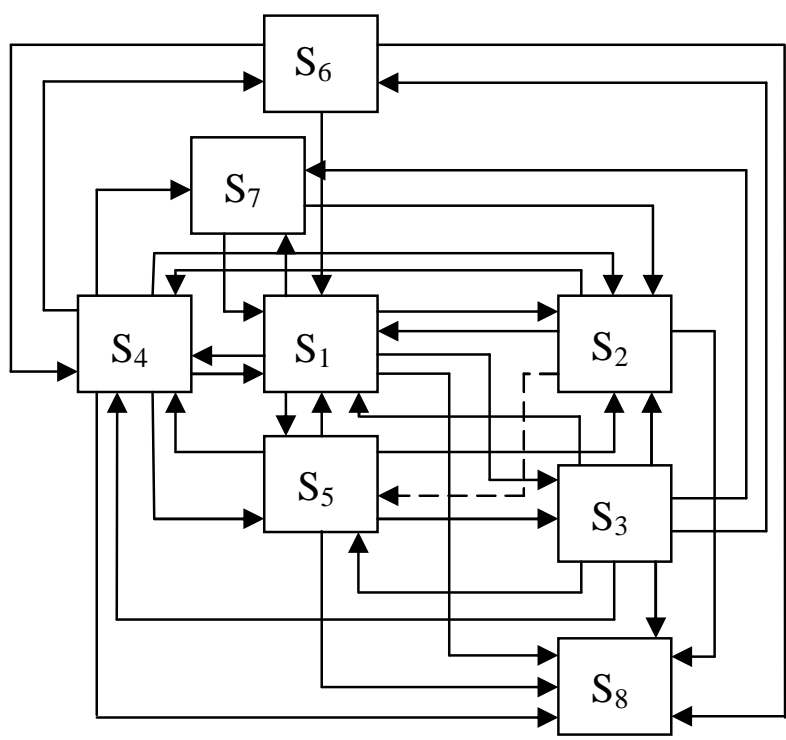

uc. 5. озмічений гр ф переходів ур хув нням стр тегій зберіг ння

н чення коефіцієнтів переходів 3 лежно від стр тегії зберіг ння предст влені в т блиці 4. 
блиця 4

н чення коефіцієнтів переходів в 3 лежності від стр тегї̈ зберіг ння

\begin{tabular}{|l|c|c|}
\hline \multicolumn{1}{|c|}{$\begin{array}{c}\text { оефі- } \\
\text { цієнт }\end{array}$} & 1 & 2 \\
\hline & 0 & 1 \\
\hline $\mathrm{k}_{31}$ & 1 & 1 \\
\hline $\mathrm{k}_{31}$ & 1 & 1 \\
\hline $\mathrm{k}_{31}$ & \multicolumn{2}{|c|}{ омер стр тегії } \\
\hline
\end{tabular}

1.5. тем тичн модель експлу т ції з собів вимірюв льної техніки військового призн чення 3 ур хув нням стр тегій первинного к лібрув ння (первинної метрологічної перевірки). озмічений гр ф переходів із одного ст ну в інший 3 ур хув нням стр тегій первинного к лібрув ння (первинної метрологічної перевірки) предст влений н рис. 6.

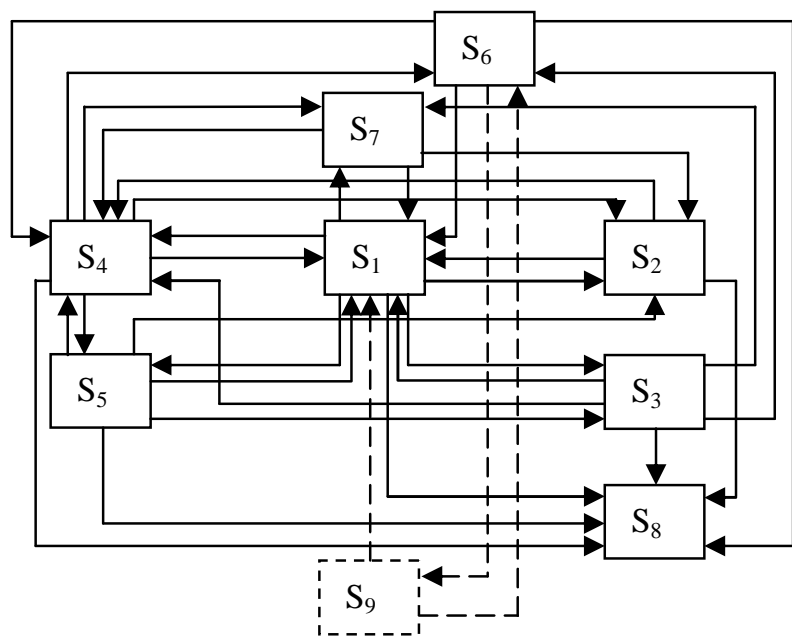

ис. 6. озмічений гр ф переходів з ур хув нням стр тегій первинногок лібрув ння (первинної метрологічної перевірки)

н чення коефіцієнтів переходів 3 лежно від стр тегії первинного к лібрув ння (первинної метрологічної перевірки) предст влені в т блиці 5 .

блиия 5

н чення коефіціснтів переходів в 3 лежності від стр тегії первинного к лібрув ння (первинної метрологічної перевірки)

\begin{tabular}{|l|c|c|c|}
\hline $\begin{array}{c}\text { оефi- } \\
\text { цієнт }\end{array}$ & \multicolumn{3}{|c|}{ омер стр тегії } \\
\hline & 1 & 2 & 3 \\
\hline $\mathrm{k}_{91}$ & 1 & 0 & 1 \\
\hline $\mathrm{k}_{96}$ & 0 & 0 & 1 \\
\hline $\mathrm{k}_{69}$ & 0 & 0 & 1 \\
\hline
\end{tabular}

1.6. тем тичн модель експлу т ції з собів вимірюв льної техніки військового призн чення 3 ур хув нням стр тегій метрологічної тест ції. озмічений гр $\phi$ переходів із одного ст ну в інший 3 ур хув нням стр тегій метрологічної тест ції предст влений н рис. 7.

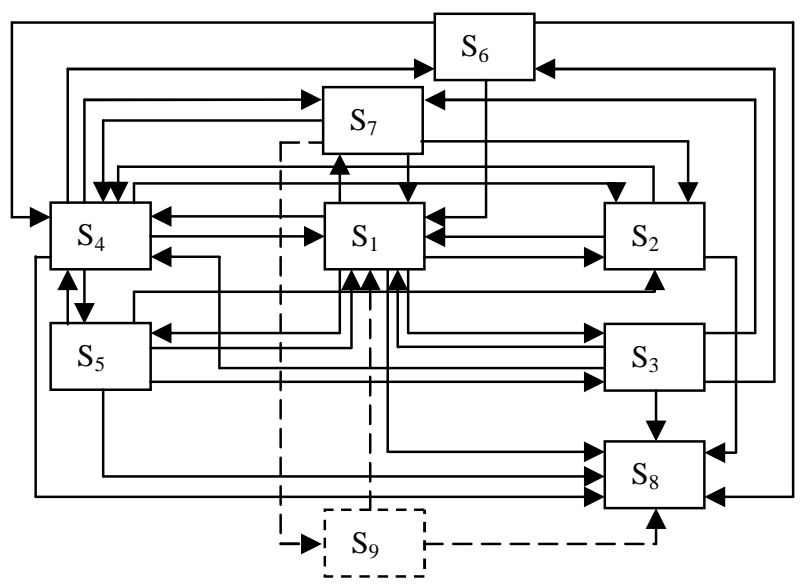

uc. 7. озмічений гр ф переходів ур хув нням стр тегій метрологічної тест ції

н чення коефіцієнтів переходів з лежно від стр тегії первинного к лібрув ння метрологічної тест ції предст влені в т блиці 6.

блиия 6

н чення коефіцієнтів переходів в з лежності від стр тегії метрологічної тест ції

\begin{tabular}{|l|c|c|}
\hline $\begin{array}{c}\text { оефi- } \\
\text { цієнт }\end{array}$ & \multicolumn{2}{|c|}{ омер стр тегії } \\
\hline & 1 & 2 \\
\hline $\mathrm{k}_{79}$ & 0 & 1 \\
\hline $\mathrm{k}_{91}$ & 0 & 1 \\
\hline $\mathrm{k}_{98}$ & 0 & 1 \\
\hline
\end{tabular}

ля визн чення вірогідностей зн ходження в кожному із ст нів $\mathrm{S}_{1}-\mathrm{S}_{9}$ необхідно вирішити систему рівнянь (1) відносно $\mathrm{P}_{1}-\mathrm{P}_{9}$ для кожної з м тем тичних моделей. е можн зробити відомими н літичними метод ми [7] бо чисельними метод ми н [10].

трим н систем м тем тичних моделей досить повно вр ховує всі можливі ст ни упродовж життєвого циклу і дозволяє проводити н ліз впливу різних пок зників н ефективність упр вління їх 


\section{ИсНОВ К И}

ким чином, в ст тті розроблено систему м тем тичних моделей експлу т ції ур хув нням стр тегій к лібрув ння (метрологічноі перевірки), технічного обслуговув ння, ремонту, зберіг ння, первинного к лібрув ння (первинної метрологічної перевірки) т метрологічної тест ції.

ідмінність 3 пропонов ної системи м тем тичних моделей від відомих моделей експлу т ції, з стосов них до , поляг $є$ у комплексному ур хув нні специфіки експлу т ції пропонов но для оцінюв ння ефективності т оптиміз ції упр вління використовув ти розроблену систему м тем тичних моделей.

\section{писок літер тури}

1. инков . н ліз ст ну системи з безпечення єдності вимірюв нь в бройних сил х кр їни $m$ концепту льнін н прямки ї̈ розвитку / . . инков// $m$ н m перспективи розвитку військової системи метрологічного з безпечення бройнихсил кр їни зр зк 2011 року: (V) н ук.-техн. конф. 25-26 вер. 2008 р.: тези доn. - ., 2008. - . 3 .

2. ридмн . . еория метрологической н дежности средств измерений / . . ридмн // змерительн я техник . - 1991. - № 11 - . 3-10.
3. ищенко . . етрологическя н дежность измерительных средств / . . ищенко, . . ветков, . . ернышов .- .. шиностроение, 2001.-96 с.

4. инков . . збыточн я модель н дежной эксплу тиии средств измерительной техники / . . инков, . . ельниченко // кр инский метрологический жмурн л. - 2004. - № 2. - . 57-60.

5. иенк эффективности $и$ п р метрический синтез метрологического обслужив ния p дио пn p туры. - .: , 1984. - 386c.

6. втом тиз иия метрологического обслужив ния промышленного предприятия / гн ткин . ., рещук . ., ривоцюк . . и др. - . cm нд ртов, 1988. - 208 c.

7. рещук.. етрологическое обеспечение эксплу т иии сложных изделий / . . решук- .. зд тельство $\mathrm{cm}$ нд ртов, 1989. - $200 \mathrm{c}$.

8. рещук . . тем тическ я модель системы

контрольно-измерительной пn р туры / . . peщук // змерительн я техник . -1987. - .№4. - . 74.

9. овременные м тем тические методы н лиз и синтез сложных систем / [ еркетов . ., л женков . ., рвец . ., селедеи . .]; под ред. . . $л$ женков . - . $\quad$, 1984. - 397 c.

10. кров . . нженерные р счёты в Mathcad. чебный курс / . . к ров. - б.: итер, 2005. $448 \mathrm{c}$.

дійщл до ред кції 6.11.2010 p.

ецензент: доктор технічних н ук, доцент . . нько, ціон льний університет “ ьвівськ політехнік ”, ьвів.

ст тье р зр бот н систем м тем тических моделей эксплу $m$ ции средств измерительной техники военного н зн чения с учетом специфики их эксплу $m$ ици. редложено для оценив ния эффективности и оптимиз ции упр вления метрологической н дежностью средств измерительной техники военного н зн чения использов ть р зр бот нную систему м тем тических моделей.

лючевые слов : систем м тем тических моделей, упр вление, метрологическ я н дежность, средств измерительной техники военного н зн чения, эффективность, оптимиз иия, метрологическое обеспечение.

\title{
SYSTEM OF MATHEMATICAL MODELS OF EXPLOITATION OF FACILITIES OF MILITARY-ORIENTED MEASURING EQUIPMENT
}

\author{
M.Ju. Jakoylev, .I. Prityka, O.E.Semenova, Y.V. Babiy
}

In the article the system of mathematical models of exploitation of facilities of military-oriented measuring equipment is developed taking into account the specifics of their exploitation. It is suggested for the evaluation of efficiency and optimization of management of facilities of measuring technique of military-oriented metrology reliability to draw on the developed system of mathematical models.

Keywords: system of mathematical models, management, metrology reliability, facilities of measuring military-oriented equipment, efficiency, optimization, metrology providing. 